This is a preprint to the final manuscript Holzberger, D. \& Schiepe-Tiska, A. (2021). Is the school context associated with instructional quality? The effects of school composition, principals, teacher collaboration, and school climate. School Effectiveness and School Improvement, 32:3. 465-485. doi: 10.1080/09243453.2021.1913190

Is the School Context associated with Instructional Quality? The Effects of School Composition, Principals, Teacher Collaboration, and School Climate Doris Holzberger* \& Anja Schiepe-Tiska ${ }^{1}$ Centre for International Student Assessment, TUM School of Education, Technical University of Munich, Munich, Germany

* Corresponding author. Doris Holzberger, Centre for International Student Assessment, TUM School of Education, Technical University of Munich, Arcisstraße 21, 80333 Munich, Germany. Tel: +49-89-289-28278. E-mail address: doris.holzberger@tum.de (Doris Holzberger).

\title{
Acknowledgment/Funding
}

We would like to thank the Research Data Centre (FDZ) at the Institute for Educational Quality Improvement (IQB), Germany, for providing the data used in the study and the German Research Foundation (DFG) for supporting this research (HO5852/1-1). 


\section{Is the School Context associated with Instructional Quality? The Effects of School Composition, Principals, Teacher Collaboration, and School Climate}

\section{Abstract}

The relevance of the school context to creating a successful learning environment and promoting teachers' instructional quality is not yet clear. In the current study, we examine whether schools differ in instructional quality (i.e., classroom management and task feedback) and whether differences between schools can be explained by school characteristics (i.e., students' school composition, school's academic track, principals' leadership, teacher collaboration, and school climate). Therefore, we model instructional quality both at teacher and school level and include multiple perspectives on the school context. German PISA 2003 data were re-analyzed, resulting in data from 1,939 teachers and their principals in 198 schools. Multi-level analyses revealed that schools differ systematically in their instructional quality. These differences were related to school composition, principals' leadership, teacher collaboration, and school climate. Accordingly, schools have the potential to promote instructional quality. However, teachers' perceptions of school characteristics are more relevant than those of the principals.

Keywords: School context, School characteristics, instructional quality, principals, multi-level analysis

\section{Introduction}

In many models of educational psychology, schools are considered to be a relevant context in which teaching (i.e., instructional quality) and learning (i.e., students' cognitive and non-cognitive development) takes place. School effectiveness research assumes that schools are important to student outcomes as mediated primarily by instructional quality (Creemers \& Reezigt, 1996). While research on teacher characteristics (e.g., knowledge, motivation, certification) and how these relate to instructional quality is flourishing (Blömeke, Busse, Kaiser, König, \& Suhl, 2016; Hill, Blazar, \& Lynch, 2015; Kunter et al., 2013), the 
relationship between school characteristics and instructional quality has not been sufficiently addressed (Reynolds et al., 2014).

If school characteristics are relevant to instructional quality, differences in schools would be reflected in differences in instructional quality. Research has shown that, although the main variance in instructional quality occurs within schools, there is also a significant amount of variation across schools (Hill et al., 2015; Wenger, Lüdtke, \& Brunner, 2018). In a study conducted across 81 participating countries in PISA, Wenger et al. (2018) analyzed between-school differences and found ICCs between .05 and .12 for a large variety of instructional quality variables (including time management, behavior management, and feedback). Using the MQI and the CLASS observational instruments to assess teachers' instructional quality by external raters, Hill et al. (2015) reported slightly larger variances at the school level for instructional support (i.e., classroom climate and teachers' interactions with students; ICC $=.19$ ), and classroom organization (i.e., behavior management and productivity of the lesson; ICC $=.12$ ).

These few studies have found that schools differ in their instructional quality. However, these studies either did not focus on explaining these variances (e.g., focusing instead on international comparison) or were unable to explain the variance (e.g., Hill et al., 2015). Therefore, in the present study we examine the role of school characteristics in instructional quality by analyzing between-school differences in instructional quality (i.e., classroom management and feedback).

In order to achieve these aims, we analyzed data from a German extension of the 2003 PISA study. As a national add on, Germany also administered a teacher questionnaire to an extended teacher sample. Thus, within and between-school variance could be examined as well as school characteristics from the perspective of both teachers and principals.

\subsection{Instructional Quality}


Instructional quality in the classroom can be regarded as the main predictor variable for student development. While instructional quality is a multi-faceted construct for which various models have been developed (Baumert et al., 2010; Pianta \& Hamre, 2009; Roehrig et al., 2012), in the present study, we focus on (1) effective classroom management, indicated by behavior and time management, and (2) providing students with feedback as an indicator of instructional support. We focused on these two dimensions as they seemed to include both content-specific and content-generic aspects (Charalambous \& Praetorius, 2018) and might be determined by both teachers (i.e., content-specific) and school factors.

Classroom management aims to use the provided learning time efficiently, maximizing students' learning opportunities (Emmer \& Stough, 2001; Evertson \& Weinstein, 2006). It is characterized by a clear structure, high levels of discipline, and a low-noise learning environment that help students to focus on the proposed learning activities. Two key aspects of classroom management are time management and behavior management (Pianta \& Hamre, 2009). Behavior management involves dealing with disturbances and refers to teachers' strategies of treating and eliminating disciplinary problems in class quickly. Time management, in turn, is aimed at minimizing the loss of realized learning time (e.g., because students do not have their working materials) in order to provide students with the maximum amount of time to deal with the learning content (i.e., effective use of learning time, cf. Carroll, 1963). Maximized time use is related to higher levels of student achievement, more effective learning processes, and positive motivational-affective outcomes (Seidel \& Shavelson, 2007).

Like these aspects of classroom organizational, providing students with feedback is an aspect of teachers' instructional support (Pianta \& Hamre, 2009). Feedback can be conceptualized as the information provided by teachers about students' learning progress and performance and aims to close the gap between intended learning goals and what has been achieved so far (Hattie \& Timperley, 2007). The most common feedback type in classrooms 
is feedback about the task (i.e., corrective feedback; Hattie \& Timperley, 2007). Feedback about the task involves explaining to students how well a task was accomplished by stating whether the answer is correct and encouraging students' to acquire more or different information to build more surface knowledge. Feedback about a task is related to higher student achievement (Hattie, 2009; Scheerens \& Bosker, 1997) and increased intrinsic motivation (Rakoczy, Klieme, Bürgermeister, \& Harks, 2008).

Although teachers may be the main determinant for instructional quality, it is reasonable to assume that classroom management and feedback are not only determined by teachers, but may also be influenced by the student body (within a class and, in turn, within a school). Moreover, teachers may receive inspiration or input from their colleagues and principals, which may also be reflected in teachers' instructional quality. We outline the theoretical considerations of the relationship between school characteristics and instructional quality in the following sections.

\subsection{School Characteristics as Predictor of Instructional Quality}

From a school effectiveness perspective, schools are assumed to be important to instructional quality (Maag Merki, Emmerich, \& Holmeier, 2015; Reynolds et al., 2014; Scheerens, 2015). However, the relationship between school characteristics and instructional quality has rarely been empirically examined. School characteristics are manifold. In particular, schools differ regarding their school track, student composition (e.g., achievement, social background), learning climate, degree of teacher collaboration, and principal leadership behavior regarding teachers (including profession development opportunities) and teaching, to name a few (OECD, 2018). These variables can be classified into two groups: nonmanipulable context variables and alterable process variables.

Context variables refer to organizational, legal, and administrative conditions that set the framework for design and decision possibilities, for example, the school track or the student composition of a school. Process variables refer to the fact that teachers (and 
principals) design differential learning environments. Similarly, schools also differ in alterable process characteristics, which include the learning climate, teacher collaboration, and principal leadership.

Both context and process variables may be reflected in teachers' instructional quality and are, therefore, relevant to understanding the mechanisms by which schools differ in their instructional quality.

\subsubsection{School Track and Student Composition}

Grouping students according to their abilities creates homogenous learning environments that allow teachers to address students' needs specifically (Betts, 2011). Particularly, when students are tracked into different schools, these schools differ not only in their student body, but also in their curricula, working and learning conditions, and their underlying pedagogical and didactical traditions.

In Germany, there are two major school tracks: an academic school track ("gymnasium") and a non-academic, vocation-oriented secondary school track. The teachers of these tracks undergo different educational programs. While teacher training for the gymnasium focuses on subject-specific content knowledge and scientific propaedeutic procedures, the training for the non-academic school track emphasizes a more practical approach with a strong pedagogical orientation (Baumert et al., 2010). This leads to differences in instructional quality across school tracks (Baumert et al., 2010; Schiepe-Tiska, 2019). Baumert et al. (2010) identified differences between non-academic and academic tracks only with regard to the cognitive and curricular level of tasks and respectful treatment of the students. Schiepe-Tiska (2019) showed that classroom management was higher at academic schools, but instructional support did not differ across school tracks.

The assignment of students to a specific school is not only determined by prior achievement but also depends on students' social background. This results in a difference in student composition between schools. Most studies that analyze the relationship between 
student composition and achievement treat the linking mechanism (i.e., instructional quality) as a "black box" (van Ewijk \& Sleegers, 2010). One explanation of this relationship is that schools and teachers adapt their instruction to fit the student body. A few studies show that in low-achieving or low SES school and classes, teachers have lower achievement expectations, teach slower, and are less cognitively demanding, and schools have more disciplinary problems (Dreeben, 1988; Harker \& Tymms, 2004; Rjosk et al., 2014). Thus, teachers in low SES schools may report more problem behavior and thus, a lower level of successful classroom management. On the contrary, due to a lower student achievement level, teachers in low SES schools may provide students with a more elaborated feedback on the task.

To conclude, school track and school composition-although eventually confounded — seem to have an impact on instructional quality at schools. While these context variables cannot easily be altered, school process characteristics seem to be relevant to how schools can promote instructional quality.

\subsubsection{Principal Leadership Behavior}

Principals play a key role in shaping the learning environment at schools (Hallinger, 2018), and their leadership behavior is assumed to be related to school outcomes (OECD, 2016). When searching for ways to promote teachers' instructional quality through principal leadership behavior, instructional leadership appears to be most applicable style (May \& Supovitz, 2011).

Principal instructional leadership encompasses several instructional tasks. Krüger, Witziers, and Sleegers (2007) describe principals who introduce new teaching ideas, evaluate the performance of students, and supervise individual teachers. Hallinger, Bickman, and Davis (1996) refer to reviewing test scores, observing classes, facilitating teacher collaboration around the instructional program, securing resources, and maintaining visibility. Finally, Heck (1990) mentions organizing the school around instruction, overseeing school 
governance, and developing activities to foster an instructionally oriented school climate as facets of instructional leadership.

Although research on principal leadership behavior is flourishing (Day \& Sammons, 2013; Wenner \& Campbell, 2016), it has predominantly investigated leadership as a relevant source for teachers' professional learning activities (Kraft \& Papay, 2014; Liu \& Hallinger, 2018; Thoonen, Sleegers, Oort, Peetsma, \& Geijsel, 2011) or as a direct influence on student achievement (Bell, 2002; Dutta \& Sahney, 2016). Although instructional quality can be considered to be a consequence of increased professional learning activities for teachers (Thoonen et al., 2011), and a proximal predictor for student outcomes, surprisingly, research is hardly considering instructional quality as mediating variable. Consequently, Hallinger (2018) pointed out that the paths through which instructional leadership impacts student learning have still not been examined. It can be assumed that when principals have a higher focus on instruction at schools disciplinary problems in class may be more easily solved and thus, teachers may report a higher level of classroom management. Similarly, when principals emphasize student performance, useful feedback strategies may also be introduced. In the present study, we focus on the relationship between instructional leadership and instructional quality.

\subsubsection{Teacher Collaboration}

The leadership behavior of principals may not only influence teachers' instructional quality and professional learning activities but may also affect the working atmosphere and promote teacher collaboration (Vanblaere \& Devos, 2016). Teacher collaboration involves a variety of activities that may be more or less relevant to instructional quality (Vangrieken, Dochy, Raes, \& Kyndt, 2015). For instance, teachers collaborate on instructional methods, activities, and assessments; during lesson planning; by visiting other classrooms; and by planning professional development activities (Y. L. Goddard, Goddard, \& Tschannen-Moran, 2007; Ronfeldt, Farmer, McQueen, \& Grissom, 2015). Moreover, collaboration can be 
distinguished between domain-specific and domain-general collaboration and can describe activities that are either across all or specific to instructional domains (Ronfeldt et al., 2015; Vangrieken et al., 2015).

In their review article, Vangrieken et al. (2015) summarize the positive (benefits) and negative consequences of teacher collaboration and categorize these effects on the student, teacher, and organizational level. Findings that predict student outcomes by teacher collaboration are heterogeneous; both positive and negative relations are found (Y. L. Goddard et al., 2007; Ronfeldt et al., 2015). The majority of positive consequences of collaboration was found on the teacher level; however, this level was not constrained to teachers' instructional quality but encompasses a variety of teacher effects, such as teacher morale and decreased workload.

Although collaboration can be assumed to foster teacher learning and consequently improve their instruction (Goddard et al., 2007), only a few studies on the relationship between collaboration and instructional quality exist. Warwas and Helm (2018), for example, found that professional learning communities (in which collaboration is one of three aspects) were related to instructional quality. This was true for the application-oriented learning environment, but not for classroom management or individual learning support. To conclude, current research on teacher collaboration and its relationship to instructional quality is far from exhaustive. Therefore, the present study intends to contribute to this research gap.

\subsubsection{School Climate}

Principal leadership and teacher collaboration may also be reflected in a school's climate. School climate can be defined as the quality and character of school life (Cohen, McCabe, Michelli, \& Pickeral, 2009). Berkowitz, Moore, Astor, and Benbenishty (2017) provide a summary of the different indicators of school climate: teacher-student relationship, disciplinary climate (problem behavior), safety, attendance, supportive behavior, academic press/achievement expectations, and parental involvement. In several (review) articles, 
indicators of school climate have been shown to be related to student outcomes (Lubienski, Lubienski, \& Crane, 2008; Thapa \& Cohen, 2013). Kuger and Klieme (2016) pointed out the importance of addressing school climate indicators on the school level, including various sources (e.g., principal and teacher ratings). We apply this approach in the present study, using teacher and principal ratings of teacher-student relationships, disciplinary climate, and academic press as indicators for school climate.

\subsection{The Present Study}

Based on the theoretical considerations discussed above, the present study contributes to the assumption of school effectiveness research that school characteristics affect instructional quality. If this assumption holds, between-school differences would be the consequence. We considered the few studies that have found between-school variance in instructional quality but were unable to explain it (Hill et al., 2015; Wenger et al., 2018). We intend to examine how school characteristics can promote instructional quality and whether these school characteristics can explain differences in instructional quality across schools. By predicting between-school differences in instructional quality, we can better understand the reasons for differences, and this, in turn, will reveal schools' potential to support teachers in providing high-quality instruction for students' positive development. In particular, we ask the following research questions:

(1) Are there differences in instructional quality between schools? (i.e., time management, behavior management, and feedback.)

(2) Can school characteristics (i.e., school's academic track, student school composition, principal leadership, teacher collaboration, and school climate) predict the three aspects of instructional quality? Is there a difference between teachers' and principals' perceptions of school characteristics?

To answer these research questions, we re-analyzed PISA 2003 data, which included data from both the principals and teachers of a school. The nested data structure enabled us to 
model the different variance components. Moreover, we used a multi-perspective approach to assess school characteristics, resulting in school-level variables with no variance within schools (e.g., context variables, principals' school ratings) and school-level aggregates, including variance within schools (e.g., teacher ratings of school characteristics).

\section{Method}

\subsection{Sample}

We re-analyzed the PISA 2003 data (Prenzel et al., 2007). Within a German extension of the international PISA sample, up to 12 mathematics and science teachers (in total, 1,939 teachers) and the principal from each of the 198 participating schools answered a questionnaire. The data can be retrieved from the Research Data Centre (FDZ) at the Institute for Educational Quality Improvement (IQB), Germany. With our dependent variables on the teacher/class level, we used the class level dataset, including data from 387 ninth grades. On average, 9.79 teachers $(S D=2.16)$ per school participated in the study. Teachers were, on average, 47.44 years old $(S D=9.39)$, and $49.20 \%$ of them were female ( $4 \%$ missing data). Principals were, on average, 53.95 years old $(S D=5.96)$ and had an average of 8.66 years $(S D=5.98)$ of principal experience at that school; $24.50 \%$ of the principals were female (6.9\% missing data). The majority of schools were public schools (87.4\%), and approximately one third of the schools were academic track schools (31\%).

\subsection{Instruments}

In the PISA, variables are assessed via questionnaires (students, teachers, principals; see Ramm et al., 2006). The variables were rated on a 4-point Likert scale. Negative items were reverse-coded so that higher ratings indicate better characteristics. The psychometric properties of the study variables are displayed in the supplementary materials (Table A.1). Confirmatory factor analyses were run in $\mathrm{R}$ with the lavaan package (Rosseel, 2012) to ensure that the selected items fit the latent dimension. The manifest scales were then used in the 
analysis. The results of the CFAs are reported in the supplementary materials (Table A.2). We interpreted the fit indexes according to $\mathrm{Hu}$ and Bentler (1999). We used academic tracks (0 non-academic, 1 academic) and schools' student composition by socioeconomic status (school-aggregated score) as covariates.

Teachers rated instructional quality on three subscales. Two were subscales for classroom management: quality of time management (six items; e.g., "I loose quite a lot of time at the beginning/end of the lesson because of students interrupting the lesson.”) and behavior management (five items; e.g., "I make sure the students are disciplined and wellbehaved"). One was a subscale for feedback on the task (five items; e.g., "In class, students receive my feedback in regard to their answers at all time").

School variables were rated by the teachers as well as the principals with nonparallelized measures. Similar to Ronfeldt et al. (2015) teachers assessed their frequency of teacher collaboration regarding teaching (six items; how often do you coordinate matters with colleagues in regard to the content, method, planning, and current topics of lessons) and the extent of their collaboration regarding general tasks (six items: dealing with homework, teaching experiences, the possibility of dealing with cross-curricular teaching topics, parental work, feasibility of reforms, experiences and new ideas from continuing/further education events). The instructional leadership behavior of principals was rated by both teachers and the principals themselves.

Teachers assessed principals' instructional leadership behavior on two subscales regarding teaching support in general (five items; e.g., "The principal is approachable and competent in questions on teaching") and perceived individual teaching support (eight items; e.g., "The principal shows me ways to optimize the learning process"). The principals rated their instructional leadership behavior with five items (e.g., "I address the subject of new teaching methods in school"). School climate was assessed again by teachers referring to schools' academic press (six items; e.g., "We are a performance-oriented school”) and 
teacher-student relationship (four items; e.g., "We have a very open, honest, friendly relationship with the students"). Moreover, principals rated the disciplinary climate as an indicator of the school climate (seven items; e.g., "Students disrespecting teachers").

\subsection{Data Analyses}

Because we used data that involved both the teacher and the school level, we employed multi-level models to account for the nested data structure. The scripts of analyses are available via the Open Science Framework:

https://osf.io/kh43t/?view_only=684dbf7caf5b4946a63349e9c4d27f2f. To examine research question 1, we estimated the amount of variance within and between schools for the school characteristics as well as the three subscales of instructional quality. In these models, we received the basic estimates for the random parts of the model.

To predict the between-school variance in instructional quality by school characteristics (research question 2), three random-intercept models were run for each of the instructional quality subscales, and predictors were added to the empty model. As the slopes for the teacher-level predictor variables did not vary significantly across schools (the deviance likelihood ratio test did not indicate an improvement of the model fit), we calculated fixed effects models. The predictor variables were included stepwise in the model.

In the first model (Model 1), we included the school context variables academic track and schools' socioeconomic student composition. Subsequently, we added the indicators for principal leadership (Model 2a), teacher collaboration (Model 2b), and school climate (Model 2c). Finally, we included all predictor variables in the overall model (Model 3). For multilevel analyses, we used the R package lme4 (Bates, Maechler, Bolker, \& Walker, 2015) with the function lmer. We included the school-level aggregates of teachers' individual ratings (person-adjusted group-means) and principals' ratings centered at the grand-mean (see Enders \& Tofighi, 2007). Moreover, we controlled for teachers' individual perceptions centered at the group-means. 


\section{Results}

\subsection{Variance Components}

With regard to the between-school variance in instructional quality, the ICC values, based on the unconditional models for each variable under investigation, revealed low to medium between-school variance (Time management: $\mathrm{ICC}=.11$, behavior management: ICC $=.06$, and feedback on the task: ICC $=.04)$. With regard to between-school variance in the teachers' ratings of school characteristics, the ICC values indicate - with the exception of teachers' perception of teacher-student relationships $($ ICC $=.05)$ —medium between-school variance, with smaller proportions regarding teacher collaboration $(\mathrm{ICC}=.11-.13)$ and higher proportions regarding leadership behavior (ICC $=.21-.26$ ) and academic press (ICC $=.25$ ). These findings indicate that schools do indeed differ in school characteristics and, to a lesser degree, instructional quality.

\subsection{Relationship Between School Characteristics and Instructional Quality}

We calculated random-intercept models to predict the between-school variance in instructional quality (see Tables 1-3). Adding the school context variables as covariates to the empty model (Model 0) showed that part of the between-school variance was explained by academic track and student composition. In schools with composed of students with high socioeconomic stats, teachers reported better time management $\left(b=.25^{*}\right)$, less behavior management $(b=-.10 *)$, and less feedback on a task $(b=-.09 *)$. School track did not significantly predict the aspects of instructional quality over and above school composition.

In the next steps, we included the indicators for principal leadership (Model 2a), teacher collaboration (Model 2b), and school climate (Model 2c). The process variables significantly predicted the variability across schools in time management, behavior management, and feedback on a task. However, differences were found for the three dependent variables. For instructional leadership by the principals, we found a significant 
prediction only for the indicator perceived as individual teaching support, predicting behavior management $\left(b=.13^{*}\right)$ and feedback on a task $(b=.14 *)$. Similarly, teacher collaboration regarding general tasks significantly predicted behavior management $\left(b=.29^{*}\right)$ and feedback on a task $\left(\mathrm{b}=.21^{*}\right)$. Finally, academic press significantly predicted time $\left(\mathrm{b}=.47^{*}\right)$ and behavior management $\left(\mathrm{b}=.20^{*}\right)$; teacher-student relationship predicted behavior management $\left(b=.10^{*}\right)$ and feedback on a task $(b=.07 *)$.

In the overall model (Model 3), controlling for interrelations between the predictor variables, ${ }^{1}$ showed that time management was significantly predicted by academic track $(b=$ $\left..15^{*}\right)$ and academic press $\left(b=.46^{*}\right)$, explaining $92 \%$ of the variance on the school level. Behavior management was significantly predicted by a school composition $\left(b=-.12^{*}\right)$, perceived teaching support by principals $\left(b=.10^{*}\right)$, teacher collaboration regarding general tasks $\left(\mathrm{b}=.21^{*}\right)$, and academic press $\left(\mathrm{b}=.18^{*}\right)$, explaining $87 \%$ of the variance on the school level. Finally, feedback on the task was significantly predicted by school composition $(b=-$ $\left..08^{*}\right)$, principals leadership regarding general instruction at school $(b=-.09 *)$, perceived teaching support by principals $(\mathrm{b}=.12 *)$, and teacher collaboration regarding general tasks $(\mathrm{b}$ $=.17^{*}$ ), explaining $71 \%$ of the variance on the school level.

$* * * * * * * * * * * * * * * * * * * * * * * * * *$

*** Insert Table $1-3$ about here ***

$* * * * * * * * * * * * * * * * * * * * * * * * * *$

\footnotetext{
${ }^{1}$ The results of the bivariate correlations on the within- and between-level are displayed in the supplementary materials (Table A.3 and Table A.4).
} 


\section{Discussion}

Schools are a relevant context in which teaching and learning take place. Surprisingly, empirical research on learning and instruction rarely includes school variables in its analyses. The present research contributes to this research gap by (1) modeling instructional quality not only as a variable at the teacher/classroom level but also at the school level, and (2) examining whether a selected set of theorized school variables may promote a learning environment in schools, thus explaining differences between schools. There are three key findings of the present study: (1) schools differ systematically in instructional quality; (2) these differences can be explained by school variables, therefore, schools have the potential to promote instructional quality; and finally, (3) when investigating schools variables, a multiperspective, multi-level approach is applicable.

\subsection{Between-school Differences in Instructional Quality}

The present investigation extends previous research by addressing the nested structure of instructional quality within and between schools. Although from theoretical considerations, schools are supposed to differ in their instructional quality, only a few studies have modeled between-school differences in instructional quality. Using multiple teacher ratings within schools, we were able to assess whether German schools differ in their instructional quality. We found that they do, with the largest differences being between schools in teachers' time management $(\mathrm{ICC}=.11)$, followed by behavior management $(\mathrm{ICC}=.06)$, and feedback on a task $(\mathrm{ICC}=.04)$. These findings are in line with the few previous studies that have revealed between-school differences to a similar extent.

Although modeling between-school differences is an under-examined topic in the present research, these findings have important implications for using instructional quality as an indicator for teacher evaluation and assessment. A requirement for using instructional quality as quality criteria for teacher assessment (Blazar, Litke, \& Barmore, 2016; Hill, Umland, Litke, \& Kapitula, 2012) is that instructional quality is comparable across schools. 
Even though the systematic differences in instructional quality between schools can be regarded as small to medium, neglecting the specific school contexts that teachers belong to may distort overall conclusions.

The findings of the present study also inform school inspections (Taut \& Rakoczy, 2016) that use instructional quality ratings, not for teacher rankings, but to measure school quality. Revealing small to medium differences between schools emphasizes that instructional quality may not be the key indicator variable in detecting differences in schools. With the importance of between-school differences to instructional quality, we encourage future research on instructional quality to address the school environment in which teaching takes place further.

\subsection{The Role of School Variables to Promote Instructional Quality}

The few existing studies that have revealed differences in instructional quality across schools did not intend or were unable to explain these differences (Hill et al., 2015; Wenger et al., 2018). Therefore, we had a closer look at sources of between-school variance in instructional quality and whether schools' contextual and process variables are associated with instructional quality. The results show specific effects with respect to the aspects of instructional quality as a dependent variable and to the school variables as predictors. Thus, the results underline the importance of having a more differentiated look rather than talking only about "the school" or "the instructional quality" when investigating underlying mechanisms.

In particular, with respect to non- (or hardly) malleable school context variables, we found that school track did not predict the three aspects of instructional quality over and above schools' socioeconomic student composition. This finding complements previous research by indicating that the differences identified in instructional quality between school track (Baumert et al., 2010; Schiepe-Tiska, 2019) are confounded by schools' student composition. With regard to student composition, we found positive relations with teachers' 
time management and negative relations with teachers' behavior management and feedback on a task. Research on students' socioeconomic status has widely revealed its importance on the individual student level (Berkowitz et al., 2017; Sirin, 2005), but also on the school level as a predictor of student development (Harwell, Maeda, Bishop, \& Xie, 2017; van Ewijk \& Sleegers, 2010).

The present study extends this research by outlining that this effect may be mediated by instructional quality. However, "the higher, the better" assumption with regard to student outcomes does not hold for instructional quality as an outcome variable. Instead, teachers seem to adapt their teaching to the study body so that students with high socioeconomic status may require less behavior management and feedback on their work.

In addition, we further examined school process variables (i.e., principal leadership behavior, teacher collaboration, and school climate). The more principals were rated as providing teaching support for their teachers, the more behavior management and feedback on a task were indicated by teachers. Interestingly, there was also a negative prediction of principals' general instructional leadership on feedback. Moreover, high achievement expectations in schools (academic press) and teacher collaboration positively contributed to time and behavior management as well as to behavior management and feedback, respectively.

These findings extend previous research that is mainly dominated by single predictor variables but do not address the interplay between various school characteristics. The findings point to schools' potential to support high quality instruction. Contrary to the context variables, we assumed that these process variables are generally malleable. However, future research should investigate how leadership, teacher collaboration, and academic press may be formed.

\subsection{Modeling School Variables from Different Perspectives}


One main advantage of the present study is that it investigates school effects using multiple perspectives and sources (Hallinger, 2018). In particular, ratings from multiple teachers within a school were examined as well as ratings from their corresponding principals. If we regard instructional quality as a relevant school characteristic, the potential analyses on the teacher level are limited. Including the school-level aggregates of teachers' perception of school variables in our analyses resulted in a substantial increase in explained variance (comparison of Model 1 and Model 3). Thus, the within school variation of teachers' perspectives in a school does not explain the differences between schools.

Investigating multiple teachers within a school and a substantive number of schools is a demanding and expensive, yet high-potential, research design. This is why we took advantage of a pre-existing dataset and performed re-analyses of PISA data. We encourage future researchers to continue this work, use the advantages of large-scale studies, and, in particular, address teacher interactions within the school context.

Furthermore, we included principals' ratings of their leadership behavior and their perception of school climate (e.g., disciplinary climate). Although the latter was significantly correlated with the three aspects of instructional quality, these ratings did not specifically help explain school differences in the regression analyses. Thus, teachers' perceptions of principals seem to be decisive. As in PISA 2003, the scales for the school variables were not formulated in parallel for the teachers and principals, and we were, unfortunately, unable to examine the agreement between principal and teacher ratings, which would have shed light on the validity of the rating source (cf. research on self-other agreement Fleenor, 2010; Lee, 2018).

\subsection{Limitations}

Due to the advantage of the nested data structure, we re-analyzed cross-sectional PISA 2003 data (based on self-report questionnaires). Consequently, the underlying causal assumption of schools predicting instructional quality cannot be investigated. Moreover, it cannot be excluded that those teachers with a high instructional quality may be particularly 
grouped in schools with a favorable context. For the school variable, a quasi-experimental design may be useful, comparing, for example, schools with higher average teacher collaboration with schools with lower average teacher collaboration.

Finally, we focused on explaining the variance of the between-school level (76\% to $95 \%$, depending on the aspect of instructional quality). The explained variance on the teacher level, $3 \%$ to $10 \%$, only indicates that schools have a rather small effect on teachers' individual teaching. However, future research should not only include individual teacher characteristics (e.g., teachers' professional knowledge, teacher motivation) to examine the interaction between teacher and school characteristics but also the conglomerate of individual teacher characteristics within schools. The conglomerate of teacher characteristics has been investigated in the field of efficacy beliefs. Collective teacher efficacy at schools (as opposed to teachers' self-efficacy beliefs) has been shown to predict differences between schools in student-level achievement (R. D. Goddard, Hoy, \& Hoy, 2000) and be influenced by leadership behavior (Ross \& Gray, 2006). Collective efficacy constitutes “a group's shared belief in its conjoint capabilities to organize and execute the courses of action required to produce given levels of attainment" (Bandura, 1997).

The re-analysis of PISA 2003 data was highly suitable to examine the research questions of the present study. Unfortunately, these data are rather limited with regard to the included teacher characteristics. We recommend that future research adapt our approach of using multiple teachers per schools to model the interplay of teacher characteristics, school effects, and instructional quality on both the teacher and the school level.

\subsection{Conclusion}

Using data from multiple teachers within several schools, the present study was able to model teachers' instructional quality not only at the teacher level but also at the school level. The results revealed that schools differ systematically in instructional quality, and thus, instructional quality should be regarded as both a classroom and school variable. Moreover, 
contrary to previous research, we investigated the ways in which schools impact instructional quality, pointing to the potential of school leadership, teacher collaboration, and academic press. Thus, the influence that schools may exert and the application of multiple perspectives of school characteristics (e.g., principals, teachers) should not be neglected when aiming to enhance instructional quality. 


\section{References}

Bandura, A. (1997). Self-efficacy: The exercise of control. New York: Freeman.

Bates, D., Maechler, M., Bolker, B., \& Walker, S. (2015). Fitting linear mixed-effects models using lme4. Journal of Statistical Software, 67(1), 1-78. doi:10.18637/jss.v067.i01

Baumert, J., Kunter, M., Blum, W., Brunner, M., Voss, T., Jordan, A., . . Tsai, Y.-M. (2010). Teachers' mathematical knowledge, cognitive activation in the classroom and student progress. American Educational Research Journal, 47, 133-180. doi:10.3102/0002831209345157

Bell, L., Bolam, R. and Cubillo, L. (2002). A systematic review of the impact of school leadership and management on student outcomes. Retrieved from London:

Berkowitz, R., Moore, H., Astor, R. A., \& Benbenishty, R. (2017). A research synthesis of the associations between socioeconomic background, inequality, school climate, and academic achievement. Review of Educational Research, 87, 425-469. doi:10.3102/0034654316669821

Betts, J. R. (2011). The economics of tracking in education. In S. M. L. W. Hanushek (Ed.), Handbook of the economics of education (pp. 341-381). Amsterdam: North-Holland.

Blazar, D., Litke, E., \& Barmore, J. (2016). What does it mean to be ranked a "high" or "low" value-added teacher? Observing differences in instructional quality across districts. American Educational Research Journal, 53, 324-359. doi:10.3102/0002831216630407

Blömeke, S., Busse, A., Kaiser, G., König, J., \& Suhl, U. (2016). The relation between content-specific and general teacher knowledge and skills. Teaching and Teacher Education, 56, 35-46. doi:10.1016/j.tate.2016.02.003

Carroll, J. B. (1963). A model for school learning. Teachers College Record, 64(8), 723-733. 
Charalambous, C. Y., \& Praetorius, A.-K. (2018). Studying mathematics instruction through different lenses. Setting the ground for understanding instructional quality more comprehensively. ZDM, 50(3), 355-366. doi:10.1007/s11858-018-0914-8

Cohen, J., McCabe, E. M., Michelli, N. M., \& Pickeral, T. (2009). School climate: Research, policy, practice, and teacher education. Teachers College Record, 111(1), 180-213.

Creemers, B. P. M., \& Reezigt, G. J. (1996). School level conditions affecting the effectiveness of instruction. School Effectiveness and School Improvement, 7(3), 197228. doi:10.1080/0924345960070301

Day, C., \& Sammons, P. (2013). Successful leadership: a review of the international literature. Reading: CfBT Education Trust.

Dreeben, R. B., R. (1988). Classroom composition and the design of instruction. Sociology of Education, 61(3), 129-142. doi:10.2307/2112622

Dutta, V., \& Sahney, S. (2016). School leadership and its impact on student achievement. International Journal of Educational Management, 30(6), 941-958. doi:10.1108/ijem12-2014-0170

Emmer, E. T., \& Stough, L. M. (2001). Classroom management: A critical part of educational psychology, with implications for teacher education. Educational Psychologist, 36(2), 103-112. doi:10.1207/S15326985EP3602_5

Enders, C. K., \& Tofighi, D. (2007). Centering predictor variables in cross-sectional multilevel models: A new look at an old issue. Psychological Methods, 12(2), 121138. doi:10.1037/1082-989X.12.2.121

Evertson, C. M., \& Weinstein, C. S. (2006). Classroom management as a field of inquiry. In C. M. Evertson \& C. S. Weinstein (Eds.), Handbook of Classroom Management (pp. 3-15). Mahwah, New Jersey: Lawrence Erlbaum Associates. 
Fleenor, J. W., Smither, J. W., Atwater, L. E., Braddy, P.W. \& Sturm, R. E. (2010). Selfother rating agreement in leadership: A review. The Leadership Quarterly, 21(6), 1005-1034. doi:10.1016/j.leaqua.2010.10.006

Goddard, R. D., Hoy, W. K., \& Hoy, A. W. (2000). Collective teacher efficacy: Its meaning, measure, and impact on student achievement. American Educational Research Journal, 37, 479-507. doi:10.3102/00028312037002479

Goddard, Y. L., Goddard, R. D., \& Tschannen-Moran, M. (2007). A theoretical and empirical investigation of teacher collaboration for school improvement and student achievement in public elementary schools. Teachers College Record, 109(4), 877-896.

Hallinger, P. (2018). Principal Instructional Leadership: From prescription to theory to practice. In G. E. Hall, L. F. Quinn, \& D. M. Gollnick (Eds.), The Wiley Handbook of Teaching and Learning (pp. 505-528). Hoboken, NJ: John Wiley \& Sons.

Hallinger, P., Bickman, L., \& Davis, K. (1996). School context, principal leadership, and student reading achievement. Elementary School Journal, 96(5), 527-550. doi:10.1086/461843

Harker, R., \& Tymms, P. (2004). The effects of student composition on school outcomes. School Effectiveness and School Improvement, 15(2), 177-199. doi:10.1076/sesi.15.2.177.30432

Harwell, M., Maeda, Y., Bishop, K., \& Xie, A. (2017). The surprisingly modest relationship between SES and educational achievement. The Journal of Experimental Education, 85, 197-214. doi:10.1080/00220973.2015.1123668

Hattie, J. (2009). Visible learning: A synthesis of over 800 meta-analyses relating to achievement. New York: Routledge.

Hattie, J., \& Timperley, H. (2007). The power of feedback. Review of Educational Research, 77(1), 91-112. doi:10.3102/003465430298487 
Heck, R. H., Larsen, T. J., \& Marcoulides, G. A. (1990). Instructional leadership and school achievement: Validation of a causal model. Educational Administration Quarterly, 26(2), 94-125. doi:10.1177/0013161X90026002002

Hill, H. C., Blazar, D., \& Lynch, K. (2015). Resources for teaching: Examining personal and institutional predictors of high-quality instruction. AERAOpen, 1(4), 1-50. doi:10.1177/2332858415617703

Hill, H. C., Umland, K., Litke, E., \& Kapitula, L. R. (2012). Teacher quality and quality teaching: Examining the relationship of a teacher assessment to practice. American Journal of Education, 118(4), 489-519. doi:10.1086/666380

Hu, L.-t., \& Bentler, P. M. (1999). Cutoff criteria for fit indexes in covariance structure analysis: Conventional criteria versus new alternatives. Structural Equation Modeling, 6, 1. doi:10.1080/10705519909540118

Kraft, M. A., \& Papay, J. P. (2014). Do supportive professional environments promote teacher development: Explaining heterogeneity in returns to teaching experience. Educational Evaluation and Policy Analysis, 36(4), 476-500. doi:10.3102/0162373713519496

Krüger, M. L., Witziers, B., \& Sleegers, P. (2007). The impact of school leadership on school level factors: Validation of a causal model. School Effectiveness and School Improvement, 18(1), 1-20. doi:10.1080/09243450600797638

Kuger, S., \& Klieme, E. (2016). Dimensions of context assessment. In S. Kuger, E. Klieme, N. Jude, \& D. Kaplan (Eds.), Assessing contexts of learning - An international perspective (pp. 3-37). Cham: Springer.

Kunter, M., Klusmann, U., Baumert, J., Richter, D., Voss, T., \& Hachfeld, A. (2013). Professional competence of teachers: Effects on instructional quality and student development. Journal of Educational Psychology, 105, 805-820. doi:10.1037/a0032583 
Lee, A. C., N. C. (2018). Seeing eye to eye: A meta-analysis of self-other agreement of leadership. The Leadership Quarterly, 29(2), 253-275. doi:10.1016/j.leaqua.2017.06.002

Liu, S., \& Hallinger, P. (2018). Principal instructional leadership, teacher self-efficacy, and teacher professional learning in China: Testing a mediated-effects model. Educational Administration Quarterly, 54(4), 501-528. doi:10.1177/0013161x 18769048

Lubienski, S. T., Lubienski, C., \& Crane, C. C. (2008). Achievement differences and school type: The role of school climate, teacher certification, and instruction. American Journal of Education, 115, 97-138. doi:10.1086/590677

Maag Merki, K., Emmerich, M., \& Holmeier, M. (2015). Further development of educational effectiveness theory in a multilevel context: from theory to methodology and from empirical evidence back to theory. School Effectiveness and School Improvement, 26(1), 4-9. doi:10.1080/09243453.2014.938930

May, H., \& Supovitz, J. A. (2011). The scope of principal efforts to improve instruction. Educational Administration Quarterly, 47(2), 332-352. doi:10.1177/0013161x10383411

OECD. (2016). School leadership for learning: Insights from TALIS 2013. Paris: OECD Publishing.

OECD. (2018). PISA for development assessment and analytical framework: Reading, mathematics, and science. Paris: OECD Publishing.

Pianta, R. C., \& Hamre, B. K. (2009). Conceptualization, measurement, and improvement of classroom processes: Standardized observation can leverage capacity. Educational Researcher, 38, 109-119. doi:10.3102/0013189X09332374

Prenzel, M., Baumert, J., Blum, W., Lehmann, R., Leutner, D., Neubrand, M., . . Schiefele, U. (2007). Programme for international student assessment 2003 (PISA 2003). 
Version: 1. IQB - Institut zur Qualitätsentwicklung im Bildungswesen. Datensatz. doi:10.5159/IQB_PISA_2003_v1.

Rakoczy, K., Klieme, E., Bürgermeister, A., \& Harks, B. (2008). The interplay between student evaluation and instruction. Zeitschrift für Psychologie/Journal of Psychology, 216(2), 111-124. doi:10.1027/0044-3409.216.2.111

Ramm, G., Prenzel, M., Baumert, J., Blum, W., Lehmann, R., Leutner, D., . . S Schiefele, U. (Eds.). (2006). PISA 2003: Dokumentation der Erhebungsinstrumente. Münster: Waxmann.

Reynolds, D., Sammons, P., De Fraine, B., Van Damme, J., Townsend, T., Teddlie, C., \& Stringfield, S. (2014). Educational effectiveness research (EER): A state-of-the-art review. School Effectiveness and School Improvement, 25(2), 197-230. doi:10.1080/09243453.2014.885450

Rjosk, C., Richter, D., Hochweber, J., Lüdtke, O., Klieme, E., \& Stanat, P. (2014). Socioeconomic and language minority classroom composition and individual reading achievement: The mediating role of instructional quality. Learning and Instruction, 32, 63-72. doi:10.1016/j.learninstruc.2014.01.007

Roehrig, A. D., Turner, J. E., Arrastia, M. C., Chirstesen, E., McElhaney, S., \& Jakiel, L. M. (2012). Effective teachers and teaching: Characteristics and practices related to positive student outcomes. In K. R. Harris, S. Graham, \& T. Urdan (Eds.), APA Educational Psychology Handbook (Vol. 2). Washington, DC: American Psychological Association.

Ronfeldt, M., Farmer, S. O., McQueen, K., \& Grissom, J. A. (2015). Teacher collaboration in instructional teams and student achievement. American Educational Research Journal, 52(3), 475-514. doi:10.3102/0002831215585562

Ross, J. A., \& Gray, P. (2006). Transformational leadership and teacher commitment to organizational values: The mediating effects of collective teacher efficacy. School 
Effectiveness and School Improvement, 17(2), 179-199.

doi:10.1080/09243450600565795

Rosseel, Y. (2012). lavaan: An R package for structural equation modeling. Journal of Statistical Software, 48(2), 1-36. doi:10.18637/jss.v048.i02

Scheerens, J. (2015). Theories on educational effectiveness and ineffectiveness. School Effectiveness and School Improvement, 26(1), 10-31. doi:10.1080/09243453.2013.858754

Scheerens, J., \& Bosker, R. J. (1997). The foundations of educational effectiveness. Oxford: Pergamon.

Schiepe-Tiska, A. (2019). School tracks as differential learning environments moderate the relationship between teaching quality and multidimensional learning goals in mathematics. Frontiers in Education, 4(4). doi:10.3389/feduc.2019.00004

Seidel, T., \& Shavelson, R. J. (2007). Teaching effectiveness research in the past decade: The role of theory and research design in disentangling meta-analysis results. Review of Educational Research, 77, 454-499. doi:10.3102/0034654307310317

Sirin, S. R. (2005). Socioeconomic status and academic achievement: A meta-analytic review of research. Review of Educational Research, 75, 417-453. doi: $10.3102 / 00346543075003417$

Taut, S., \& Rakoczy, K. (2016). Observing instructional quality in the context of school evaluation. Learning and Instruction, 46, 45-60. doi:10.1016/j.learninstruc.2016.08.003

Thapa, A., \& Cohen, J. (2013). A review of school climate research. Review of Educational Research, 83, 357-385. doi:10.3102/0034654313483907

Thoonen, E. E. J., Sleegers, P. J. C., Oort, F. J., Peetsma, T. T. D., \& Geijsel, F. P. (2011). How to Improve Teaching Practices: The role of teacher motivation, organizational 
factors, and leadership practices. Educational Administration Quarterly, 47(3), 496536. doi:10.1177/0013161X11400185

van Ewijk, R., \& Sleegers, P. (2010). The effect of peer socioeconomic status on student achievement: A meta-analysis. Educational Research Review, 5, 134-150. doi:10.1016/j.edurev.2010.02.001

Vanblaere, B., \& Devos, G. (2016). Relating school leadership to perceived professional learning community characteristics: A multilevel analysis. Teaching and Teacher Education, 57, 26-38. doi:10.1016/j.tate.2016.03.003

Vangrieken, K., Dochy, F., Raes, E., \& Kyndt, E. (2015). Teacher collaboration: A systematic review. Educational Research Review, 15, 17-40. doi:10.1016/j.edurev.2015.04.002

Warwas, J., \& Helm, C. (2018). Professional learning communities among vocational school teachers: Profiles and relations with instructional quality. Teaching and Teacher Education, 73, 43-55. doi:10.1016/j.tate.2018.03.012

Wenger, M., Lüdtke, O., \& Brunner, M. (2018). Übereinstimmung, Variabilität und Reliabilität von Schülerurteilen zur Unterrichtsqualität auf Schulebene: Ergebnisse aus 81 Ländern [Interrater agreement, variability and reliability of student ratings of instructional quality at the school-level: Results from 81 countries]. Zeitschrift für Erziehungswissenschaft, 21(5), 929-950. doi:10.1007/s11618-018-0813-3

Wenner, J. A., \& Campbell, T. (2016). The theoretical and empirical basis of teacher leadership: A review of the literature. Review of Educational Research, 1-38. doi:10.3102/0034654316653478 
Table 1

Multi-level Regression with School Variables as Predictors for Time Management

\begin{tabular}{|c|c|c|c|c|c|c|}
\hline & Model 0 & Model 1 & Model 2a & Model 2b & Model 2c & $\begin{array}{c}\text { Model } \\
3\end{array}$ \\
\hline \multirow[t]{2}{*}{ Intercept } & $2.17 *$ & $2.86^{*}$ & $2.84 *$ & $2.86^{*}$ & $2.85^{*}$ & $2.84 *$ \\
\hline & $(0.02)$ & $(0.03)$ & $(0.03)$ & $(0.03)$ & $(0.02)$ & $(0.02)$ \\
\hline Academic track & & 0.06 & 0.09 & 0.07 & $0.14 *$ & $0.15^{*}$ \\
\hline$(1=$ academic $)$ & & $(0.06)$ & $(0.06)$ & $(0.05)$ & $(0.06)$ & $(0.06)$ \\
\hline School's SES & & $0.25^{*}$ & $0.25^{*}$ & $0.28 *$ & 0.09 & 0.10 \\
\hline composition & & $(0.05)$ & $(0.05)$ & $(0.05)$ & $(0.05)$ & $(0.05)$ \\
\hline \multicolumn{7}{|l|}{ Teacher ratings } \\
\hline \multicolumn{7}{|l|}{ Leadership - } \\
\hline $\begin{array}{l}\text { general teaching } \\
\text { at school }(\mathrm{T})\end{array}$ & & & $(0.08)$ & & & $(0.07)$ \\
\hline Leadership - & & & & & & \\
\hline perceived & & & 0.09 & & & 0.06 \\
\hline individual & & & $(0.08)$ & & & $(0.08)$ \\
\hline support (T) & & & & & & \\
\hline Teacher & & & & & & \\
\hline collaboration & & & & 0.14 & & 0.6 \\
\hline regarding & & & & $(0.09)$ & & $(0.09)$ \\
\hline teaching $(\mathrm{T})$ & & & & & & \\
\hline Teacher & & & & & & \\
\hline & & & & 0.11 & & 0.04 \\
\hline collaboration & & & & $(0.12)$ & & $(0.11)$ \\
\hline
\end{tabular}


general tasks

(T)

Climate -

academic press

$0.47^{*} \quad 0.46^{*}$

$(0.06) \quad(0.07)$

(T)

Climate -

teacher-student

relationship (T)

$(0.05) \quad(0.05$

Principal ratings

$\begin{array}{lll}\text { Instructional } & -0.01 & -0.02\end{array}$

leadership (P)

$(0.04)$

Climate -

disciplinary

$-0.05 \quad-0.05$

$(0.04) \quad(0.04)$

climate $(\mathrm{P})$

\begin{tabular}{lccccc}
\hline $\mathrm{R}^{2}$ - Level 1 & 0.01 & 0.02 & 0.01 & 0.04 & 0.05 \\
$\mathrm{R}^{2}$ - Level 2 & 0.60 & 0.66 & 0.61 & 0.90 & 0.92
\end{tabular}

Note. $(\mathrm{T})$ teacher rating, $(\mathrm{P})$ principal rating. Teachers' individual perceptions were included as covariates in the Models 2a, 2b, 2c, and 3.

Table 2

Multi-level Regression with School Variables as Predictors for Behavior Management

\begin{tabular}{lcccccc}
\hline & $\begin{array}{l}\text { Model } \\
0\end{array}$ & Model 1 & Model 2a & Model 2b & Model 2c & Model 3 \\
\hline Intercept & $3.51^{*}$ & $3.55^{*}$ & $3.53^{*}$ & $3.54^{*}$ & $3.53^{*}$ & $3.52^{*}$ \\
& $(0.01)$ & $(0.02)$ & $(0.02)$ & $(0.01)$ & $(0.01)$ & $(0.02)$
\end{tabular}


Academic track

$\begin{array}{lllll}-0.04 & -0.03 & -0.03 & -0.01 & -0.00 \\ (0.04) & (0.04) & (0.03) & (0.03) & (0.04)\end{array}$

School's SES

$-0.10^{*}$

$-0.10^{*}$

$-0.08 *$

$-0.14^{*}$

$-0.12 *$

composition

$(0.03)$

$(0.03)$

(0.03)

(0.03)

(0.03)

Teacher ratings

Leadership -

general

$-0.01$

$-0.03$

teaching at

$(0.05)$

school (T)

Leadership -

perceived

$0.13 *$

$0.10 *$

individual

(0.05)

support (T)

Teacher

collaboration

$-0.06$

regarding

(0.05)

teaching (T)

Teacher

collaboration

regarding

$0.29 *$

$0.21 *$

general tasks

(0.07)

(T)

Climate -

academic press
$0.10 *$
$0.07 *$
(0.03)
(0.03)

(T) 
Climate -

teacher-student

$0.20 * \quad 0.18 *$

relationship (T)

$(0.04) \quad(0.04)$

Principal ratings

$\begin{array}{lll}\text { Instructional } & -0.01 & -0.01\end{array}$

leadership (P)

$(0.02)$

Climate -

disciplinary

$0.05 \quad 0.05$

climate $(\mathrm{P})$

\begin{tabular}{lccccc}
\hline $\mathrm{R}^{2}$ - Level 1 & -0.02 & 0.00 & 0.01 & 0.02 & 0.03 \\
$\mathrm{R}^{2}$ - Level 2 & 0.62 & 0.73 & 0.71 & 0.79 & 0.87
\end{tabular}

Note. (T) teacher rating, $(\mathrm{P})$ principal rating. Teachers' individual perceptions were included as covariates in the Models 2a, 2b, 2c, and 3.

Table 3

Multi-level Regression with School Variables as Predictors for Feedback on the Task

\begin{tabular}{lcccccc}
\hline & Model & Model 1 & Model 2a & Model 2b & Model 2c & Model 3 \\
& 0 & & & & \\
\hline Intercept & $3.29^{*}$ & $3.48^{*}$ & $3.48^{*}$ & $3.48^{*}$ & $3.48^{*}$ & $3.48^{*}$ \\
& $(0.01)$ & $(0.01)$ & $(0.01)$ & $(0.01)$ & $(0.01)$ & $(0.01)$ \\
Academic track & & 0.02 & 0.02 & 0.03 & 0.02 & 0.003 \\
(1 = academic) & & $(0.03)$ & $(0.03)$ & $(0.03)$ & $(0.03)$ & $(0.03)$ \\
School's SES & & $-0.09^{*}$ & $-0.09^{*}$ & $-0.08^{*}$ & $-0.09 *$ & $-0.08^{*}$ \\
composition & & $(0.03)$ & $(0.03)$ & $(0.03)$ & $(0.03)$ & $(0.03)$
\end{tabular}

Teacher ratings 
Leadership -

general

teaching at

school (T)

Leadership -

perceived

individual

support (T)

Teacher

collaboration

regarding

teaching $(\mathrm{T})$

Teacher

collaboration

regarding

general tasks

(T)

Climate -

academic press

(T)

Climate -

teacher-student

relationship (T)

Principal ratings
$-0.09 *$

(0.04)

(0.04)

$0.14^{*}$

$0.12^{*}$

(0.04)

$(0.04)$

$-0.05$

$-0.04$

$(0.05)$

$0.21 *$

$0.17 *$

(0.06)

(0.07)

$0.07 * \quad 0.06$

$(0.03) \quad(0.03)$

$\begin{array}{ll}0.07 & 0.07\end{array}$

$(0.04) \quad(0.04)$ 


$\begin{array}{lcr}\text { Instructional } & 0.00 & 0.01 \\ \text { leadership (P) } & (0.02) & (0.02)\end{array}$

Climate -

disciplinary

$0.01 \quad 0.00$

climate $(\mathrm{P})$

$(0.02) \quad(0.02)$

\begin{tabular}{lccccc}
\hline $\mathrm{R}^{2}$ - Level 1 & 0.02 & 0.04 & 0.08 & 0.06 & 0.10 \\
$\mathrm{R}^{2}$ - Level 2 & 0.63 & 0.71 & 0.65 & 0.62 & 0.71
\end{tabular}

Note. (T) teacher rating, $(\mathrm{P})$ principal rating. Teachers' individual perceptions were included as covariates in the Models 2a, 2b, 2c, and 3. 
